\title{
Consequences of climate-driven biodiversity changes for ecosystem functioning of North European rocky shores
}

\author{
S. J. Hawkins ${ }^{1,2, *}$, H. E. Sugden ${ }^{1}$, N. Mieszkowska ${ }^{2}$, P. J. Moore ${ }^{2,3}$, E. Poloczanska ${ }^{4}$, \\ R. Leaper ${ }^{5}$, R. J. H. Herbert ${ }^{6,7}$, M. J. Genner ${ }^{2,8}{ }^{\text {, P. S. Moschella }}{ }^{2,9}$, R. C. Thompson ${ }^{10}$, \\ S. R. Jenkins ${ }^{1,2}$, A. J. Southward ${ }^{2, \mp}$, M. T. Burrows ${ }^{11}$ \\ ${ }^{1}$ School of Ocean Sciences, Bangor University, Menai Bridge, Anglesey LL59 5AB, UK \\ ${ }^{2}$ Marine Biological Association of the UK, The Laboratory, Citadel Hill, Plymouth PL1 2PB, UK \\ ${ }^{3}$ School of Natural Sciences, Edith Cowan University, Joondalup, Western Australia 6027, Australia \\ ${ }^{4}$ Climate Adaptation Flagship, CSIRO Marine \& Atmospheric Research, PO Box 120, Cleveland, Queensland 4163, Australia \\ ${ }^{5}$ Commonwealth Environment Research Facilities Program Marine Biodiversity Hub: Prediction Program, Tasmanian \\ Aquaculture and Fisheries Institute, University of Tasmania, Locked Bag 49, Hobart 7001, Australia \\ ${ }^{6}$ Medina Valley Field Centre, Dodnor Lane, Newport, Isle of Wight PO30 5TE, UK \\ ${ }^{7}$ School of Conservation Sciences, Bournemouth University, Christchurch House, Talbot Campus, Poole, Dorset BH12 5BB, UK \\ ${ }^{8}$ School of Biological Sciences, University of Bristol, Woodland Road, Bristol BS8 1UG, UK \\ ${ }^{9}$ CIESM - The Mediterranean Science Committee, 16 bd de Suisse, MC 98000, Monaco \\ ${ }^{10}$ Marine Biology and Ecology Research Centre, Marine Institute, University of Plymouth, Drake Circus, Plymouth PL4 8AA, UK \\ ${ }^{11}$ Scottish Association for Marine Sciences, Dunstaffnage Marine Laboratory, Oban, Argyll PA37 1QA, UK
}

\begin{abstract}
We review how intertidal biodiversity is responding to globally driven climate change, focusing on long-term data from rocky shores in the British Isles. Physical evidence of warming around the British Isles is presented and, whilst there has been considerable fluctuation, sea surface temperatures are at the highest levels recorded, surpassing previous warm periods (i.e. late 1950s). Examples are given of species that have been advancing or retreating polewards over the last 50 to 100 yr. On rocky shores, the extent of poleward movement is idiosyncratic and dependent upon life history characteristics, dispersal capabilities and habitat requirements. More southern, warm water species have been recorded advancing than northern, cold water species retreating. Models have been developed to predict likely assemblage composition based on future environmental scenarios. We present qualitative and quantitative forecasts to explore the functional consequences of changes in the identity, abundance and species richness of gastropod grazers and foundation species such as barnacles and canopy-forming algae. We forecast that the balance of primary producers and secondary consumers is likely to change along wave exposure gradients matching changes occurring with latitude, thereby shifting the balance between export and import of primary production. Increases in grazer and sessile invertebrate diversity are likely to be accompanied by decreasing primary production by large canopy-forming fucoids. The reasons for such changes are discussed in the context of emerging theory on the relationship between biodiversity and ecosystem functioning.
\end{abstract}

KEY WORDS: Climate change $\cdot$ Intertidal $\cdot$ Range shifts $\cdot$ Biodiversity $\cdot$ Ecosystem functioning · Northeast Atlantic

Resale or republication not permitted without written consent of the publisher

\section{INTRODUCTION}

Marine biodiversity and ecosystems are responding to global climate change (Southward et al. 1995, Hawkins et al. 2003, Parmesan \& Yohe 2003). Major shifts in the distribution of plankton (Beaugrand et al. 2002, Beaugrand \& Reid 2003), fish (Perry et al. 2005, Dulvy et al. 2006), subtidal benthic invertebrates (e.g. Ling et al. 2008, Ling et al. 2009) and intertidal species (see Harley et al. 2006, Helmuth et al. 2006 for reviews) 
have been recorded in recent years. Coastal and nearshore biodiversity loss is also occurring due to regional and local-scale impacts (see e.g. Ling 2008, Polunin 2008 for reviews) such as overfishing and its side effects (Kaiser et al. 2007), pollution (Terlizzi et al. 2005), recreational pressures (Gray 1997, Dayton et al. 2005) and habitat loss due to coastal development (Airoldi \& Beck 2007). Direct responses of biodiversity to global climate-driven change are superimposed on these smaller-scale processes. There are growing local-scale impacts due to human mitigational responses to climate change (e.g. offshore windfarms) which will increase further as tidal and wave energy schemes come on stream. Human adaptation to climate change will also impact coastal ecosystems, particularly as coastal defences (Airoldi et al. 2005, Burcharth et al. 2007) proliferate in response to rising sea levels and stormier seas (Bindoff et al. 2007).

Here we take a synoptic view of changes in intertidal biodiversity in response to climate change (updating Helmuth et al. 2006) and explore the implications of these changes for ecosystem functioning, building on Hawkins et al. (2008). We draw on a combination of published and unpublished long-term studies, modelling and experiments to synthesize changes underway in intertidal biodiversity and forecast their likely consequences for ecosystem functioning. Our focus is the intertidal zone of the North East Atlantic, particularly the British Isles and Ireland, for which there are extensive historical data sets and a rich history of experimental studies (reviewed in Southward et al. 1995, 2005, Helmuth et al. 2006, Hawkins et al. 2008). Recent national (e.g. Marine Environmental Change Network and MarClim in the UK) and European networks (e.g. MarBEF LargeNet) have helped retrieve and collate much of the data discussed below. We only consider responses to temperature and associated environmental variables and increased storminess for which there are reasonable predictions of future states on a 25 to 100 yr time scale (summarised in IPCC 2007). To keep the review manageable, the impacts of reducing $\mathrm{pH}$ of the oceans are not considered. Furthermore, such impacts are also likely to act on a longer time scale (50 to $100+y r)$, although recent work has emphasized that significant changes could occur much more rapidly than originally anticipated, and may even be under way (Wootton et al. 2008).

We first outline historic fluctuations and changes in abundance and geographic distribution that are underway at the species level, before suggesting potential trajectories over the next 50 to 100 yr. Contrasts are made between advancing southern species and northern species that are likely to retreat. The species-specific nature of these changes are highlighted (see also Helmuth et al. 2006). We consider assemblage level changes by synthesising summaries of published work on the role of biological interactions in modulating climate change responses (Poloczanska et al. 2008) and give a preliminary report of statistically based modelling of the response of functionally important canopy-forming fucoids to rising temperatures and stormier seas. The mechanisms involved are discussed and gaps in knowledge and uncertainties identified. We speculate on the likely consequences for biodiversity of the loss of major habitat-forming canopy species as well as implications for the balance between primary and secondary production along wave action and latitudinal gradients. Present and future patterns and underlying processes are then placed in the context of emerging theory on the relationship between biodiversity and ecosystem functioning (Hector et al. 1999, Loreau et al. 2002, Hooper et al. 2005, Balvanera et al. 2006), derived primarily from terrestrial studies (e.g. Naeem et al. 1996, Tilman et al. 2006) but also aquatic systems (see Emmerson et al. 2001, Naeem 2006, Solan et al. 2006, Griffin et al. 2008). Counter to theory, increasing biodiversity of grazers is likely to be accompanied by decreasing productivity of canopyforming algae-reasons for this apparent paradox are discussed.

\section{SPECIES DISTRIBUTIONS: PAST AND PRESENT}

\section{Environmental context}

Fig. 1 shows the sea surface temperatures (SST) since 1870 at key locations around the British Isles. Those for Plymouth are shown separately for clarity, as most ecological data are available for this region, with time series stretching back 50 to 100 yr (see Southward 1980, Southward et al. 1995, 2005, Hawkins et al. 2003 for reviews). These data illustrate that the western side of the UK is warmer than the colder waters of the North Sea and Eastern Channel (see also Sheppard 2004, Woehrling et al. 2005). Considerable interannual and interdecadal variation is also shown, with warm periods (end of the 19th and beginning of the 20th century, and the late 1950s) followed by switches to colder temperatures. From the 1920s onwards, there was a period of warming but with much fluctuation until 1962, when, following the extreme winter of 1962-1963 (Crisp 1964), conditions were generally much cooler until the mid-1980s. Since 1987, conditions have become much warmer, typified by milder winters due to prevalence of positive North Atlantic Oscillation index years, with predominantly westerly air flow in winter across northern Europe (Mackenzie \& Schiedek 2007).

Over the last 100 yr, climate has driven major fluctuations and distributional shifts in this region (e.g. South- 

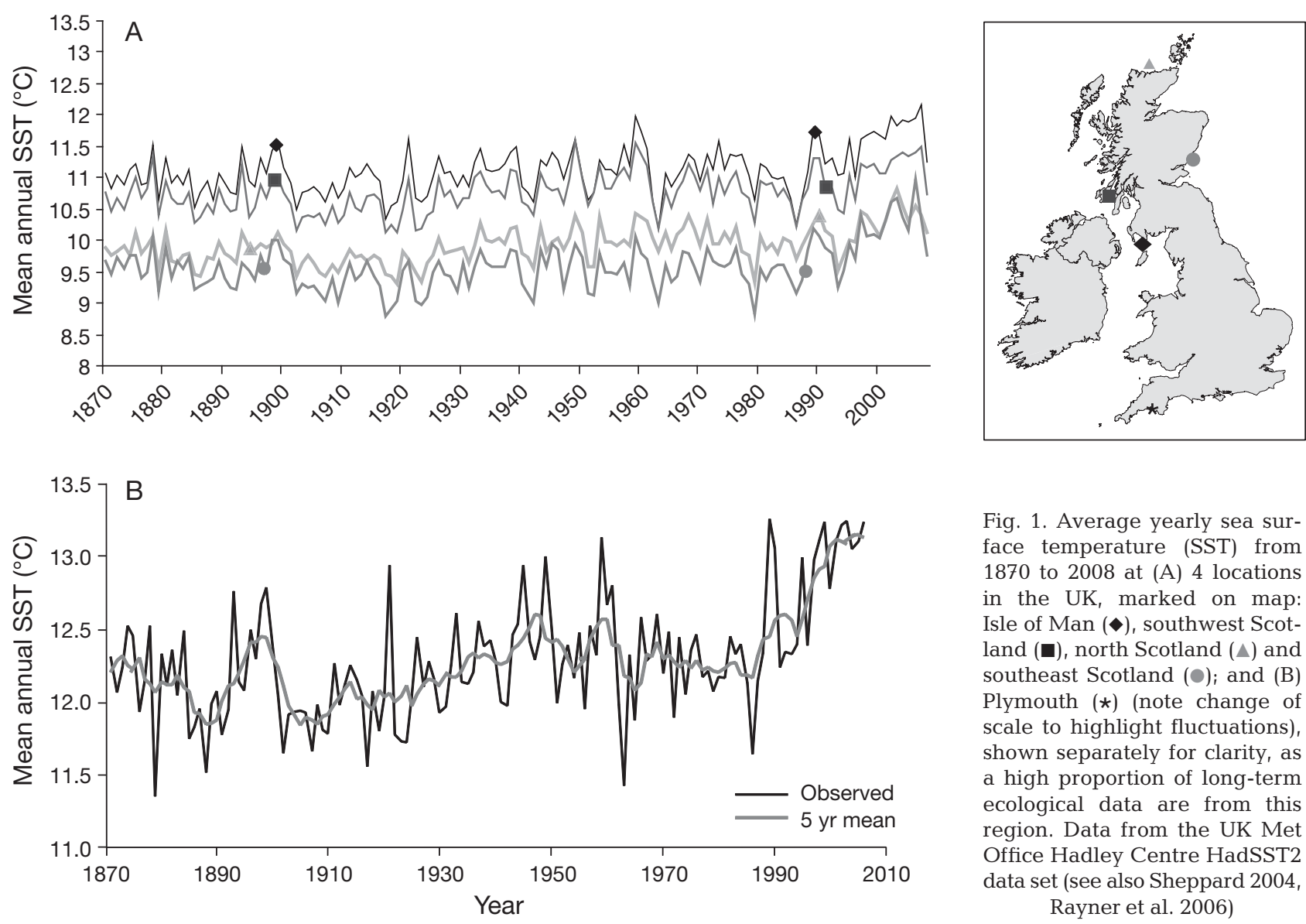

Fig. 1. Average yearly sea surface temperature (SST) from 1870 to 2008 at (A) 4 locations in the UK, marked on map: Isle of Man ( $\bullet$, southwest Scotland ( $\boldsymbol{\square})$, north Scotland $(\boldsymbol{\Delta})$ and southeast Scotland (๑); and (B) Plymouth $(*)$ (note change of scale to highlight fluctuations), shown separately for clarity, as a high proportion of long-term ecological data are from this region. Data from the UK Met Office Hadley Centre HadSST2 data set (see also Sheppard 2004, Rayner et al. 2006)

ward 1980). In recent years, poleward shifts with associated increases in abundance of southern species and reductions in northern species have been observed in plankton (Beaugrand et al. 2001), fish (Beare et al. 2004, Genner et al. 2004, Perry et al. 2005) and benthos (Hiscock et al. 2004). Phenological shifts in relation to climatic fluctuations have been observed in plankton (Edwards \& Richardson 2004) and nekton (Sims et al. 2001, 2004). Many of these changes in offshore systems have been paralleled onshore, which is perhaps not surprising given the prevalence of pelagic early lifestages of most intertidal species (Southward et al. 2005). Thus the intertidal zone can be considered a proxy for broad-scale changes in nearshore waters, with the added bonus of being easy to access, inexpensive to sample and experimentally tractable, allowing explorations of underlying processes. Hence we focus on intertidal systems in the present study.

\section{Historical patterns}

It has long been known that numerous marine species reach their biogeographic limits around the British Isles (Forbes 1858). Warm-water southern species ex- tend northwards from the Atlantic coasts of North Africa and the Mediterranean, just reaching the coasts of Britain and Ireland, while a lesser number of coldwater northern boreal species have their southern distributional limits at the same latitudes (Southward \& Crisp 1954a, Crisp \& Southward 1958, Lewis 1964, Southward et al. 1995, Hiscock et al. 2004). Thus a boundary zone straddles the British Isles: many species reach their recorded poleward limits in the western English Channel between Plymouth and the Isle of Wight, between St. David's Head in South Wales and Anglesey in North Wales, on the northwest coast of Ireland or on the western and northern coasts of Scotland. Some species extend around the north of Scotland and penetrate into the colder waters of the North Sea (e.g. Chthamalus spp., Crisp et al. 1981). There are also some southern species which have reached northern France but have not crossed the Channel (e.g. Haliotis tuberculata and Gibbula pennanti). Conversely, some northern cold water species have become very rare in the south and west of Britain and Ireland, although they can re-appear in greater abundance further south in Europe in colder waters around Brittany (e.g. Alaria esculenta) and in areas with upwelling in northern Spain and Portugal (fucoid algae, Semibalanus bala- 
noides). There are also boreal species such as Strongylocentrotus droebachiensis and the Fucus distichus complex that have been recorded as far south as Shetland and Orkney and the northern Scottish mainland (Lewis 1964, Southward et al. 1995).

\section{Recent changes}

Biogeographic range limits of many of the species described above were remarkably stable over much of the latter half of the 20th century (Crisp \& Southward 1958, Lewis 1964, Southward et al. 1995), particularly in the region of the mid English Channel from Portland Bill to the Isle of Wight. Some trimming of ranges of southern species did take place following mortalities during the extremely cold winter of 1962-1963 (Crisp 1964), particularly in North Wales. During this period, some of the most striking changes were not in range shifts, but instead changes in abundance that took place in many species, including barnacles (Southward 1967, 1991) and limpets (Kendall et al. 2004).

Over the last decade, there have been some recent major range extensions in response to warming from the early 1990s onwards. In parallel, relative abundances of warm-water species have increased, and those of northern species have declined. Table 1 summarises these changes for key species. Southern trochids (Osilinus lineatus, Gibbula umbilicalis) have increased in abundance and their ranges have extended in northern Scotland, Northern Ireland, North Wales and the eastern English Channel (Mieszkowska et al. 2007). A southern species of limpet, Patella depressa, which decreased in abundance in the 1980s compared to the 1950s (Kendall et al. 2004), has largely recovered to the levels of abundance in the previous warm period in the 1950s. In some places it is now much more common, although it has not re-extended in great numbers beyond the Lleyn Peninsula in North Wales. Chthamalus species have increased in abundance and Semibalanus balanoides has declined (Southward 1991). The recorded ranges of Patella ulyssiponensis, Melarhaphe neritoides and Perforatus (Balanus) perforatus (Herbert et al. 2003) have also extended eastwards along the English Channel coast. The most spectacular advances have been in the trochid $G$. umbilicalis along the English Channel coast; it now reaches Kent, an eastward extension of over $240 \mathrm{~km}$. In contrast, Chthamalus species have not breached the barrier of the Isle of Wight (Herbert et al. 2007, 2009).

Further south in Europe, there has been evidence of a northward range extension of southern species. Patella rustica was previously absent from the cold upwelling region of northern Portugal and Galicia, but reappeared on the warmer Basque coast (e.g. Fischer-
Piette 1936, 1955). Recently, this species has penetrated a dispersal barrier in northern Portugal associated with relaxation of upwelling (Lima et al. 2006, 2007b). Algal species have expanded or contracted northwards since the 1960s (Lima et al. 2007a). Southern species have generally advanced poleward; the picture is less clear for northern species, with both advances and retreats relative to baselines established by surveys during the 1950s and 1960s by Ardré (1971). Geographic range extensions and contractions are likely to continue into the future. The complex topography of the British Isles, with many sea gaps (i.e. between France and England, Ireland and Scotland) and stretches of soft coast providing barriers to dispersal, may hinder spread of rocky shore species which could live further north (Kendall et al. 1987).

Similar changes have been recorded in the intertidal and shallow subtidal zones in various other locations around the world such as North America, Europe and Australia (see Harley et al. 2006, Helmuth et al. 2006, Parmesan 2006, 2007, Poloczanska et al. 2007; for reviews, see also Ling et al. 2008, 2009). There have also been die-offs of intertidal (Harley 2008) and subtidal benthos due to episodes of extreme high temperatures, particularly in the Mediterranean (Coma et al. 2009). Furthermore, wholesale shifts in rocky reef ecology have been observed in the vicinity of the southeastern Australian climate change hotspot (after Poloczanska et al. 2007), whereby range extension of the habitat-modifying sea urchin Centrostephanus rodgersii has occurred (Ling et al. 2008).

\section{CHANGES WITHIN ASSEMBLAGES, AND FORE- CAST OF FUTURE COMMUNITY STATES}

Most work on biological responses to climate change has concentrated on suites of individual species rather than on whole assemblages (but see Blight \& Thompson 2008 for work on kelp holdfast assemblages). Hence there is a need to anticipate broader assemblage-level impacts by drawing inference from geographic comparisons reinforced by modelling and experimentation. In particular, the role of biological interactions in modelling climate-driven changes is crucial to fill this gap in understanding (Burrows \& Hawkins 1998, Burrows et al. 2008, Poloczanska et al. 2008).

\section{Climate and competitive interactions}

The classic textbook example of competitive exclusion is the experimental work by Connell (1961) showing that the mid- and low-shore Semibalanus balanoides (then Balanus balanoides) outcompeted high 


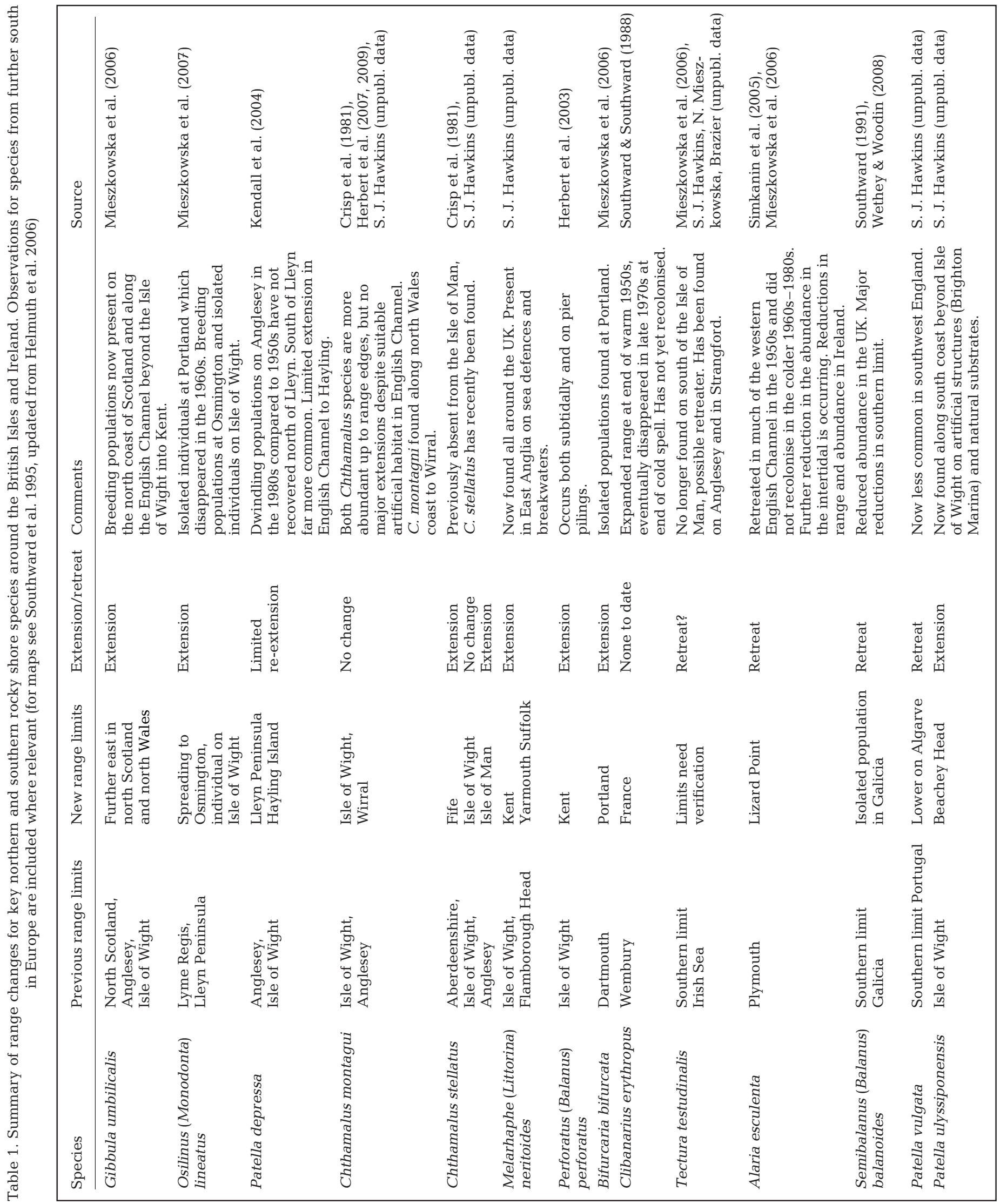


shore Chthamalus montagui (then C. stellatus). Earlier, Southward \& Crisp (1954a,b, 1956) had suggested that changes in climate mediate competition between these species (see Wethey 1980, 1982 for similar work on $S$. balanoides and $C$. fragilis in the UK and northeast USA). This work led to an extensive 40 yr time series (Southward 1967, 1991, Southward et al. 1995, 2005) encompassing 20 to 30 sites in southwest England, which showed fluctuations in counts of southern warmtemperature chthamalids (C. stellatus and C. montagui were split by Southward 1976) and the northern boreal-cold temperate $S$. balanoides were broadly linked to temperature with a lag of 1 to $2 \mathrm{yr}$ on shores in southwest England.

Southward's data sets have been used as the basis of a statistical and mechanistic modelling study by Poloczanska et al. (2008) to make predictions of likely future climate scenarios on the outcomes of competition between these species (Fig. 2). A correlative study confirmed the lag of $2 \mathrm{yr}$ with SST (Southward 1991), which was used as an integrative proxy for climatic conditions. This analysis also identified late spring/ early summer as being the sensitive period. Moreover, using path analysis, the direct nature of the relationship of temperature with Semibalanus balanoides was highlighted; there was a highly significant negative effect of warm weather on numbers of $S$. balanoides, presumably acting on the vulnerable juvenile stage. In contrast, there was no significant direct effect on Chthamalus species (lumped in the analysis, but mainly C. montagui at the high and mid-levels analysed). There was, however, a very strong negative relationship with $S$. balanoides, indicating an indirect effect due to competition. Release from competition occurred in warm years.

Populations were simulated using a space-limited model based on the work of Roughgarden et al. (1985, 1994) and validated by hindcasting against the original time series. Various forms of the model were derived. A solely physically driven model simulated Semibalanus populations well, but Chthamalus numbers were only predicted accurately when interspecific competition was included in the model. On this basis, a model involving both temperature and competition was used to explore low and high emissions scenarios (UK Climate Impacts Programme [UKCIP], Hulme et al. 2002). Even under low emissions scenarios, Semibalanus balanoides, the species which was dominant in the southwest in the 1930s (Moore \& Kitching 1939) is predicted to become locally extinct. It is, however, likely to persist in estuarine refuges and in coastal areas abutting deeper, colder water (Brittany, North Cornwall and Land's End; Crisp \& Southward 1958) as it once did at the extreme south of its range in Spain (Wethey \& Woodin 2008). Recent work by Wethey \& Woodin
(2008) has shown that $S$. balanoides is virtually extinct in Galicia (northern Spain), just persisting in a few isolated locations. Under high emissions scenarios, S. balanoides will go locally extinct more quickly, scaling up to loss over much of the coastline of south and western Britain, southwest Ireland and Brittany. In estuaries, $S$. balanoides faces competition from Elminius modestus, which was not included in the models. This Australasian immigrant, that arrived and established $60 \mathrm{yr}$ ago, has locally replaced $S$. balanoides as the dominant barnacle in areas of reduced salinity.

Responses of barnacles to changing climate have also been explored with other modelling approaches. Svensson et al. (2005) showed the importance of return frequency of failure years for population dynamics of the single annual brooding Semibalanus balanoides, drawing on data collected in a European-scale study of barnacle recruitment (Jenkins et al. 2000). Coupled matrix models of Chthamalus montagui (Hyder et al. 2001) and S. balanoides populations have also been used to explore future persistence in the face of recruitment variability (Svensson et al. 2006).

\section{Changes in fucoid canopies}

In northern Europe, fucoids predominate on sheltered shores, but can extend some way out into more exposed habitats (Lewis 1964). Further south they are more restricted to sheltered environments, with species such as Fucus vesiculosus eventually only being found in estuarine refuges (Ballantine 1961). In a warming world, the dynamic balance would be expected to shift from shores dominated by primary producing and shelter-providing fucoids with their high associated biodiversity (Thompson et al. 1996), to suspension feeder (barnacles and mussels) dominated areas with many limpets and other grazers, as in southern Europe (Ballantine 1961, Southward et al. 1995). This trend would be reinforced by stormier seas which are also predicted (Bindoff et al. 2007). Thus we have undertaken preliminary statistically based modelling studies on how changes in wave action and temperature should influence the distribution of canopyforming fucoid species.

The MarClim project undertook broad-scale surveys of much of the coastline of the British Isles and Ireland. In parallel with this work, Burrows et al. (2008) derived an algorithmic tool to predict wave exposure based on an extension of the map-based method devised by Thomas (1986). This can predict exposure to wave action down to a resolution of approximately $200 \mathrm{~m}$ on a European scale. The MarClim data set of categorical abundance of fucoids was then related to wave exposure using a multinomial logistic regression approach. 

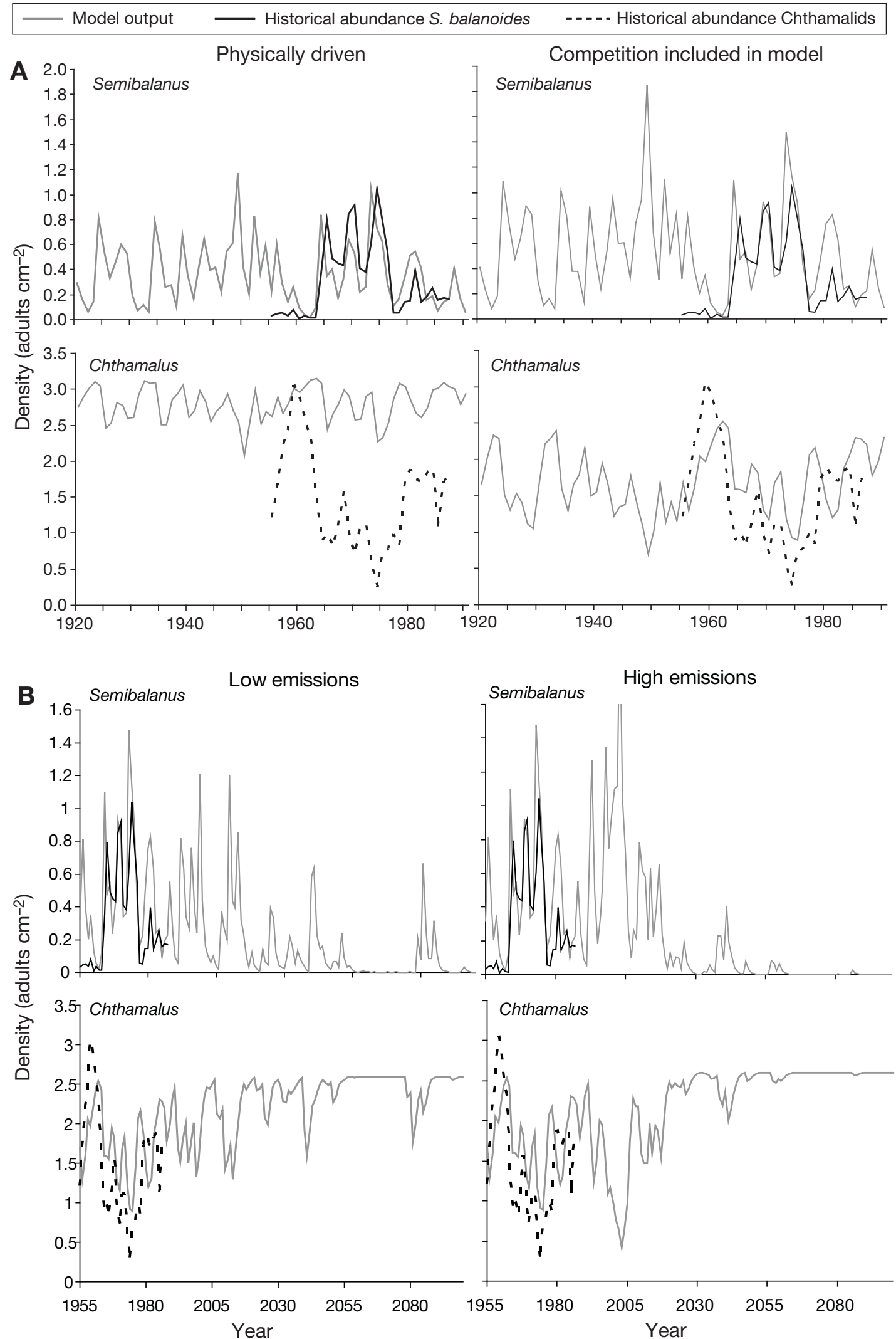

Fig. 2. (A) Models simulating densities of the northern species Semibalanus balanoides and southern species of Chthamalus with and without competition. These are compared against Southward's time series (B). Using the competition-based model which fitted best, simulations of the future under high and low emissions scenarios are shown (after Poloczanska et al. 2008) 
The frequency of occurrence of shores with different categories of algal abundance was then related to wave exposure and winter minimum SST. Forecasts of the future abundance of canopy-forming fucoid algae could then be made using different scenarios of increasing temperature and wave action (i.e. UKCIP, Hulme et al. 2002, IPCC 2007).

Fig. 3 illustrates how the major canopy-forming algae, Ascophyllum nodosum, is forecast to respond to increasing temperatures and wave exposure driven by increasing wind speed. This approach has been extended to a suite of other canopy-forming fucoids. Table 2 shows the proportion of sites where Ascophyllum and others would be 'abundant' ( $>30 \%$ cover) on the Crisp \& Southward (1958) abundance scale (the other categories are common, frequent, occasional, rare and not found). Fucus serratus is remarkably resilient, reflecting its ability to occur at moderately exposed to exposed sites low on the shore. F. serratus canopies reduce diversity of understorey algae and invertebrates due to their sweeping action (Hawkins \& Harkin 1985, Jenkins et al. 1999b), including markedly reducing recruitment of barnacles (Hawkins 1983, Jenkins et al. 1999c). Ascophyllum would appear to be surprisingly resilient, perhaps due to gradients in morphology, with stunted short plants being able to persist in surprisingly exposed conditions once established. This is despite the known susceptibility of its germlings to wave action (Miller \& Vadas 1984). F. vesiculosus would be resilient to small changes, but exhibits a sharp threshold with further increases in wave action. Pelvetia would also be expected to decrease by over $10 \%$ with modest increases in wave action. F. spiralis appears most vulnerable, with a reduction greater than $20 \%$. High shore

A Temperature

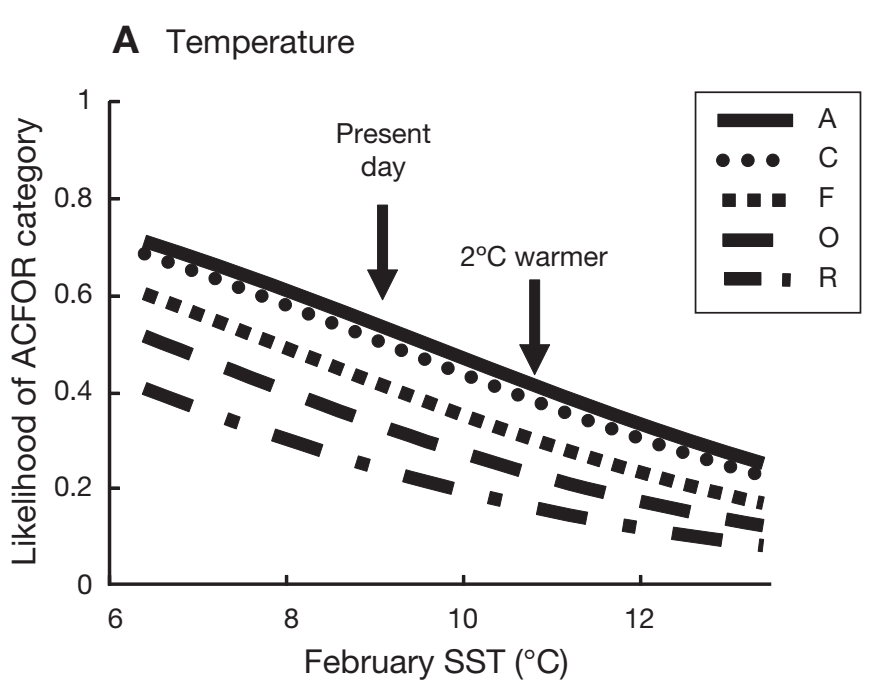

Fucus canopies are known to facilitate settling barnacles and protect high shore sub-canopy algae (Hawkins 1983, Leonard 2000, Ingolfsson \& Hawkins 2008). Ascophyllum also facilitates a diverse algal understorey which rapidly dies once the canopy is removed (Jenkins et al. 1999a). Patches of F. vesiculosus provide a refuge for a diverse assemblage of invertebrates and algae (Thompson et al. 1996) which would diminish if cover contracted. There are strong gradients of sea temperature across the British Isles that can fall as low as $6^{\circ} \mathrm{C}$ in the enclosed Irish Sea and continentally influenced southern North Sea. Thus we forecast that temperature rises along with increased wave action will act together to reduce fucoid canopy cover.

The balance between fucoid algae and suspension feeding barnacles has long been known to be modulated by limpet grazing (Southward 1964). Proliferation of algae occurs on more exposed shores when limpets are experimentally removed (Jones 1948, Hawkins 1981, Jenkins et al. 2005, Coleman et al. 2006) or killed by oil spills and their clean up (Southward \& Southward 1978). Algal growth is also high during early successional stages after placement of new structures in the sea (Hawkins et al. 1983, Moschella et al. 2005). Recent work has also shown that Ascophyllum is vulnerable to limpet grazing (Davies et al. 2008), perhaps due to milder winters encouraging limpet recruitment coupled with increased wave action. Further south in Europe (Brittany), more anecdotal observations suggest Ascophyllum is being reduced due to limpet grazing (Lorenzen 2007, S. J. Hawkins \& N. Mieszkowska pers. obs.). Such biological interactions will further compound the effects of rising temperatures and increased wave action. Subtle behavioural and facilitative effects

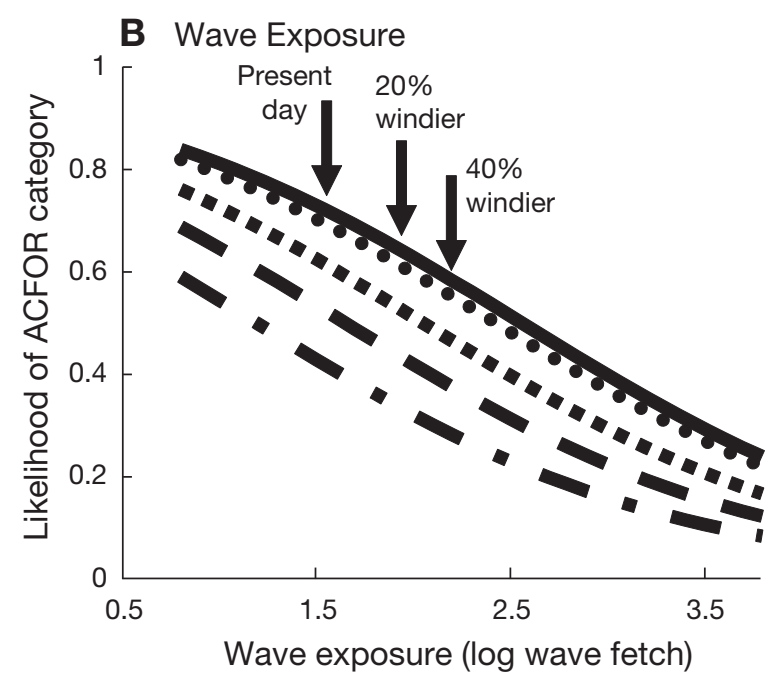

Fig. 3. Ascophyllum nodosum. Outputs of multinomial logistic regression modelling of present day distributions versus winter sea surface temperatures (SST; February) and wave fetch; a climate envelope model for Ascophyllum nodosum. The predicted shifts along the ACFOR category (Abundant, Common, Frequent, Occasional and Rare) with (A) increased SST of $2^{\circ} \mathrm{C}$ and (B) wind speeds of 120 and $140 \%$ are highlighted showing subsequent decreases in this key species 
Table 2. Expected percentage loss of MarClim sites where listed species are presently Abundant ( $>30 \%$ cover) on the Crisp \& Southward (1958) scale with 20 and $40 \%$ windier conditions

\begin{tabular}{|lcc|}
\hline Species & \multicolumn{2}{c|}{ Increase in wind speed (\%) } \\
& 20 & 40 \\
\hline Ascophyllum nodosum & 6 & 11 \\
Fucus serratus & No change & No change \\
Fucus spiralis & 21 & 32 \\
Fucus vesiculosus & 8 & 20 \\
Pelvetia canaliculata & 11 & 18 \\
\hline
\end{tabular}

may also occur. Patella vulgata aggregates under Fucus clumps and dies or migrates when fucoid clumps are removed (Hartnoll \& Hawkins 1985, Moore et al. 2007a, Hawkins et al. 2008). This effect becomes more pronounced with increasing numbers of $P$. depressa, a southern species of limpet that does not aggregate under Fucus (Moore et al. 2007a). The consequences of $P$. vulgata aggregation behaviour have been modelled and greater cover of fucoids persists when aggregation occurs (Burrows \& Hawkins 1998, Johnson et al. 1998). This, along with changes in species composition of dominant limpet grazers, has the potential to influence both the dynamics and structure of shores with fucoid and barnacle mosaics (Leonard 2000).

\section{OVERVIEW AND DISCUSSION}

\section{Mechanisms driving change}

At range edges there are ecological limits on the ability of adults to survive and reproduce, and of propagules and larvae to reach suitable sites for successful recruitment (Hutchins 1947). Range extensions are ultimately driven by increased abundance and reproductive success of populations within the range, which provide the propagules for consistent and successful recruitment at the range edges. This pattern has been recently demonstrated following the range extension of the sea urchin Centrostephanus rodgersii in Australia (Ling et al. 2008, 2009). Physical barriers to larval dispersal may be a proximate factor setting a particular limit (Gaines et al. 2007); however, new populations at range limits also need to establish sufficient numbers to overcome low density Allee effects, and thus become self-sustaining and/or inter-connected within a meta-population network (Hughes et al. 1997). Range contractions occur when species chronically fail to recruit or due to occasional extreme events, such as the 1962-1963 cold winter in northern Europe (Crisp 1964), or warm events such as have recently occurred in the Mediterranean (Coma et al. 2009) and the Pacific coast of North America (Harley et al. 2006). Clearly, recruitment processes are ultimately responsible for range expansions in sessile marine species, but recruitment fluctuations are also important in determining the intensity of interactions within an assemblage of species and hence community structure.

The importance of recruitment driving change is clearly illustrated by population data for Osilinus lineatus (Mieszkowska et al. 2007). The range of this species retracted in North Wales from Anglesey to the south side of the Lleyn Peninsula in 1962-1963, following the extremely cold winter. Subsequent recovery and recolonisation of sites was hindered by $25 \mathrm{yr}$ of predominantly colder weather. In recent years, O. lineatus has breached the barrier of the Lleyn and is now abundant on Anglesey, with odd individuals recruiting beyond the Great Orme $\sim 52 \mathrm{~km}$ beyond previous records. In addition, range extensions of 2 chthamalid species have occurred in the Irish Sea. Chthamalus stellatus has extended $\sim 77 \mathrm{~km}$ from the nearest populations in North Wales to the Isle of Man, and C. montagui has extensively colonised artificial structures and natural rock along the North Wales coast as far as the Wirral where only a single individual had been recorded in the 1950s by A. J. Southward (129 km, S. J. Hawkins pers. obs.). The range of C. montagui has also extended down the east coast of Scotland $\sim 156 \mathrm{~km}$ from Aberdeen to Fife (M. T. Burrows pers. obs.). In contrast to the case in the North Sea and Irish Sea, both chthamalid species have failed to penetrate beyond the Isle of Wight, despite effective reproduction right up to the range edges (Herbert et al. 2007, 2009).

Our work, and that by other authors, demonstrates that responses are species- and habitat-specific (e.g. Lima et al. 2007a, Jones et al. 2009, Pearson et al. 2009). Together, this body of work suggests that the likelihood of range extensions will be determined by a combination of life history traits including reproductive mode, fecundity, larval behaviour and larval duration, all of which have the potential to influence dispersal capability (Gaines et al. 2007). Thus it seems unlikely that whole assemblages will shift simultaneously, in contrast to plankton in very open pelagic systems (Beaugrand et al. 2001). Interestingly, the greatest advances have been made by species such as Gibbula umbilicalis with a short larval life history stage $(<3 \mathrm{~d})$ and generalist habitat requirements (Mieszkowska et al. 2006). This species appears to have made repeated small advances to consolidate along the south coast of England, perhaps aided by artificial habitat provided by sea defences.

\section{Southern advancers, northern persisters?}

Meta-analyses of a variety of marine and terrestrial taxa have shown that more species are advancing 
polewards than are retreating (Parmesan 1996, Parmesan \& Yohe 2003). Studies of intertidal species in Portugal (Lima et al. 2007a) and the British Isles (summarized in Mieszkowska et al. 2005, Helmuth et al. 2006) reveal a similar pattern. This could just be an artefact of there being more southern species available to advance from a greater diversity of clades. There may, however, be a mechanistic explanation. Where warmtemperate and cold-temperate intertidal species coexist, it is likely that the colder water taxon may be competitively superior in terms of growth rates and maximum body size. This is certainly the case for barnacles and limpets. The boreal Semibalanus balanoides clearly grows faster and outcompetes Lusitanian chthamalids (Southward \& Crisp 1954b, Connell 1961, Herbert et al. 2007, Poloczanska et al. 2008, Herbert et al. 2009), while Patella vulgata grows faster and outperforms P. depressa (Boaventura et al. 2002, Moore et al. 2007b). It has been known since Thorson (1950) that many cold-temperate and boreal species are single brooders/spawners with reproduction linked to spring blooms (e.g. S. balanoides) or the secondary autumn peak in production (e.g. P. vulgata). This can lead to boom or bust recruitment with occasional massive recruitment events (Connell 1961, Connell et al. 1984, Kendall et al. 1985, Hansson et al. 2003). In contrast, southern species are often multiple brooders/ spawners (Burrows et al. 1992) with more trickle-like recruitment. Hot weather probably releases them from competition with colder water species (Poloczanska et al. 2008). A combination of greater competitive ability and occasional massive recruitment events may explain why northern species can still persist. However, several years of poor recruitment would be likely to lead to rapid non-linear decline of northern species (Svensson et al. 2006), unless there are refuges such as estuaries from which they can recolonise.

\section{Implications for biodiversity and ecosystem functioning}

Warmer temperatures with associated desiccation stress will reduce recruitment of fucoids by directly influencing survival, but also indirectly by suppressing growth and reducing the likelihood of escapes from grazing (Hawkins 1981, Thompson et al. 2004). Escapes of fucoids are more likely on dense barnacle cover (Hawkins 1981). Thus switches from Semibalanus balanoides to smaller chthamalids reduce the probability of escapes occurring which could scale up from patches to whole shores (Jenkins et al. 2005). Increases in gastropod diversity will also increase the diversity of grazing methods that are employed with habitat patches (Hawkins et al. 1989), combining to increase mortality of germlings $\left(\mathrm{O}^{\prime}\right.$ Connor \& Crowe 2005). Increased numbers of mid- to high shore Osilinus lineatus (Mieszkowska et al. 2007) are likely to impact both Fucus spiralis and Pelvetia canaliculata at their lower limits, adding to mortality at their upper limit due to an increased frequency of extreme hot weather events (see Schonbeck \& Norton 1978, Hawkins \& Hartnoll 1985). P. canaliculata and F. spiralis are at risk from localised extinction events at hot spots (Helmuth et al. 2006), which may eventually scale up to whole sections of coastline.

As juvenile and adult fucoid mortality will increase due to both grazing and with wave action, exposed shorelines become characterised by a lower density of adult plants (Jonsson et al. 2006). Therefore, rougher seas and more frequent extreme events (Hulme et al. 2002), and greater grazer diversity as additional species are added, would be likely to reduce biomass and production of canopy-forming macroalgae. There could be a shift along wave exposure gradients leading to fewer areas dominated by large primary producers relative to those dominated by secondary producers, as currently occurs in southern Europe (Coleman et al. 2006). Additionally, it seems likely that fast-growing Semibalanus balanoides will be replaced by slower growing chthamalid barnacles, lowering secondary productivity of filter feeders. With fewer canopy species there would be less export of algal detritus from the system: many shores may become net importers of production from nearshore planktonic communities (Fig. 4, based on Hawkins et al. 1992).

The British Isles and Ireland are largely surrounded by shallow water, and major upwelling does not occur, in contrast to further south in Europe off the Portuguese and Spanish coasts and elsewhere in the world. Thus differences caused by changes in upwelling and recruitment regimes (e.g. Lima et al. 2006, Menge et al. 2009) are unlikely to occur around the British Isles, although regional-scale differences can occur due to differences in run-off and embayment influencing both nutrient status and larval retention (Burrows et al. 2009).

\section{Higher biodiversity, lower production?}

The general ecological literature abounds with studies exploring the links between biodiversity, ecological processes and ecosystem functioning ( $\mathrm{O}^{\prime}$ Connor \& Crowe 2005, Bremner 2008, Griffin et al. 2008, 2009, Maggi et al. 2009). Many single trophic level studies have shown a positive relationship between assemblage diversity, usually quantified as species richness, and production using biomass as a proxy (e.g. Hector et al. 1999). Together, our forecast-based statistical modelling and comparisons with lower latitudes in 


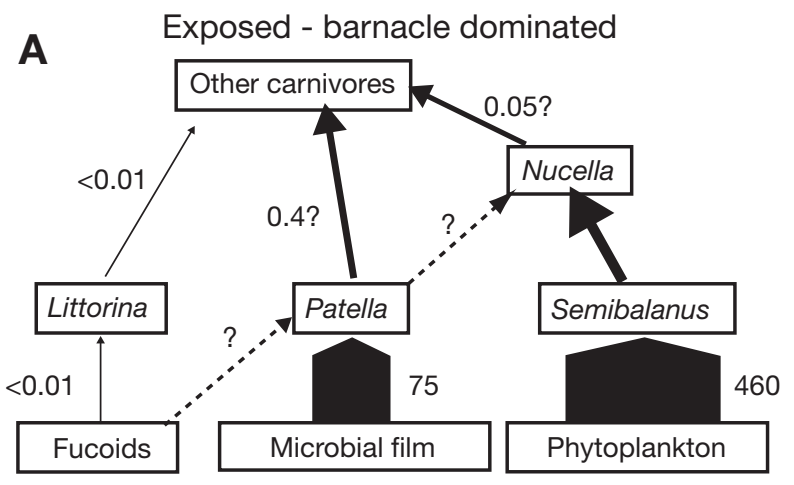

Semi-exposed - patchy Fucus-barnacle mosaics
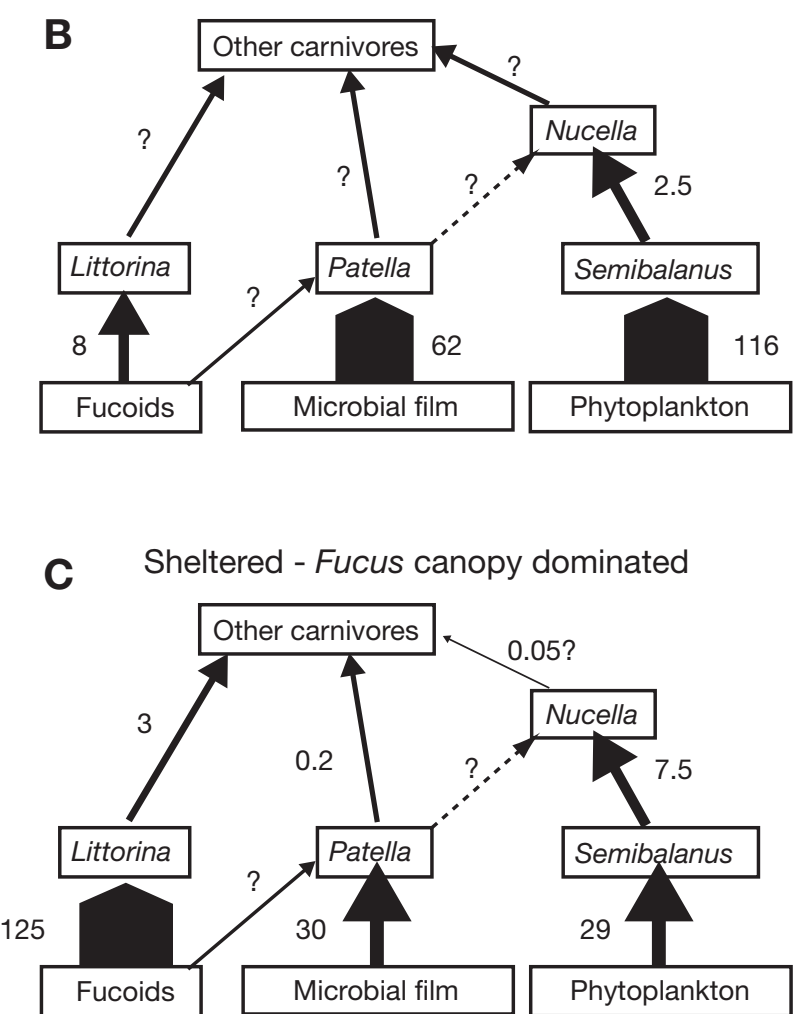

Fig. 4. Major flows of energy $\left(\mathrm{gC} \mathrm{m}^{-2} \mathrm{yr}^{-1}\right)$ on (A) exposed, barnacle-dominated shores; (B) semi-exposed, patchy Fucusbarnacle mosaic shores; and (C) sheltered, Fucus canopydominated shores on the Isle of Man, UK, typical of northern Britain where Semibalanus is the dominant mid-shore barnacle (adapted from Hawkins et al. 1992, Raffaelli \& Hawkins 1999). Arrow width indicates relative size of energy flow. Dotted arrows indicate interactions needing further clarification. (?) Value unknown or uncertain

Europe indicates that grazer diversity is likely to increase whilst production of canopy-forming algae is expected to decrease. This pattern does not match emerging theory; there are, however, good explanations for this apparent paradox. Different processes are occurring at different trophic levels that are ultimately driven by underlying physical forcing which biological processes modify. Warming and increased wave action are likely to favour grazing gastropods, many of which are from southern clades and are more diverse and abundant in southern Europe (Ballantine 1961, Lewis 1964, Hawkins \& Hartnoll 1983, Hawkins et al. 1992, Southward et al. 1995). Even across the British Isles, grazer diversity is much less in north Britain than the southwest (Southward et al. 1995). Grazing limpets also predominate numerically on more exposed shores in Europe (Lewis 1964, Coleman et al. 2006, Burrows et al. 2009). Cooler, more sheltered conditions favour fucoids, a northern clade. Grazers prevent establishment of fucoids, but wave action primarily acts on persistence of adult plants (Jonsson et al. 2006), although adult plants can also be consumed (Davies et al. 2007). Increased grazer diversity would be expected to reduce the probability of fucoid algae escapes given the greater range of feeding mechanisms involved in a more diverse grazer guild (Hawkins et al. 1989). Warmer, drier weather is also likely to reduce fucoid recruitment and early survival (Thompson et al. 2004). There may be changes in productivity in microbial films with different diversity of grazers, but this remains unexplored to date and such production is likely to be much less than that of macroalgae (Hawkins et al. 1992). Theoretically driven studies of the relationship between biodiversity and ecosystem functioning are now beginning to address multitrophic interactions, but this work is in its infancy (e.g. O'Connor \& Crowe 2005, Bremner 2008, Griffin et al. 2008). More work is needed on early stage survival of algae and interactions with a variety of grazers (but see Kordas \& Dudgeon 2009). A combination of long-term observations with experiments and modelling should unravel these complex processes to turn forecasts into more precise predictions of future states of ecosystems, their structure and ultimately their functioning.

\section{CONCLUSIONS}

Rapid changes are occurring in the distribution patterns of rocky intertidal species on a European scale. Rocky shore species can serve as cost-effective sentinels for changes in nearshore ecosystems, such as in plankton and fish (Southward 1980, Southward et al. 1995, 2005). Key organisms, such as gastropod grazers, space-occupying barnacles and canopy-forming algae, make useful study taxa for predictive modelling due to experimentally derived knowledge of ecological processes that generate spatial and temporal changes in abundance. In a warming climate, the balance between grazers/suspension feeders and fucoids is likely to alter. With the probability of algal escapes from 
grazing being lower, there will be increased interactions between environmentally induced stress and increased grazing pressure on early stages of multiple species (Jenkins et al. 2005, Coleman et al. 2006). There will be less shelter from canopy-forming species due to changes in identity and increasing diversity within the grazing guild, leading to lower biodiversity and productivity with reduced export of detritus.

Acknowledgements. S.J.H., P.J.M., M.T.B., E.P. and N.M. were funded by the MarClim consortium (www.mba.ac.uk/ marclim; Countryside Council for Wales, The Crown Estate, Department for Environment and Rural Affairs, English Nature, Environment Agency, Joint Nature Conservation Committee, Scottish Executive, Scottish Natural Heritage, States of Jersey and the Worldwide Wildlife Foundation). S.J.H. was also supported by NERC via a grant-in-aid funded fellowship and the Oceans 2025 programme. S.J.H. and P.J.M were also supported by NERC urgency grant no. NE/E000029/1 and S.J.H. and S.R.J. were supported by NERC small grant no. NE/E010482/1. M.J.G. was supported by a Great Western Research Fellowship. We thank all those who assisted with the fieldwork. H.E.S., S.J.H., N.M. and S.R.J. received support from the MarBEF consortium. The late A. J. Southward contributed much to this work right up until he passed away. We owe much to his pioneering efforts and dogged continuation of decadal time series.

\section{LITERATURE CITED}

Airoldi L, Beck MW (2007) Loss, status and trends for coastal marine habitats of Europe. Oceanogr Mar Biol Annu Rev 45:345-405

Airoldi L, Abbiati M, Beck MW, Hawkins SJ and others (2005) An ecological perspective on the deployment and design of low-crested and other hard coastal defence structures. Coast Eng 52:1073-1087

Ardré F (1971) Contribution a l'etude des algues marines du Portugal. II. Ecologie et Chorologie. Bull Cent Etud Rech Sci Biarritz 8:359-574

Ballantine WJ (1961) A biologically defined exposure scale for the comparitive description of rocky shores. Field Stud $1: 1-19$

Balvanera P, Pfisterer AB, Buchmann N, He JS, Nakashizuka T, Raffaelli D, Schmid B (2006) Quantifying the evidence for biodiversity effects on ecosystem functioning and services. Ecol Lett 9:1146-1156

$>$ Beare D, Burns F, Jones E, Peach K and others (2004) An increase in the abundance of anchovies and sardines in the north-western North Sea since 1995. Glob Change Biol 10:1209-1213

Beaugrand G, Reid PC (2003) Long-term changes in phytoplankton, zooplankton and salmon related to climate. Glob Change Biol 9:801-817

Beaugrand G, Ibañez F, Lindley JA (2001) Geographical distribution and seasonal and diel changes in the diversity of calanoid copepods in the North Atlantic and North Sea. Mar Ecol Prog Ser 219:189-203

Beaugrand G, Reid PC, Ibanez F, Lindley JA, Edwards M (2002) Reorganization of North Atlantic marine copepod biodiversity and climate. Science 296:1692-1694

Bindoff NL, Willebrand J, Artale V, Cazenave A and others (2007) Observations: oceanic climate change and sea level. In: Solomon S, Qin D, Manning M, Chen Z and oth- ers (eds) Climate change 2007: the physical science basis. Contribution of Working Group 1 to the Fourth Assessment Report of the Intergovernmental Panel on Climate Change. Cambridge University Press, Cambridge

Blight AJ, Thompson RC (2008) Epibiont species richness varies between holdfasts of a northern and a southerly distributed kelp species. J Mar Biol Assoc UK 88:469-475

Boaventura D, da Fonseca LC, Hawkins SJ (2002) Analysis of competitive interactions between the limpets Patella depressa Pennant and Patella vulgata L. on the northern coast of Portugal. J Exp Mar Biol Ecol 271:171-188

- Bremner J (2008) Species' traits and ecological functioning in marine conservation and management. J Exp Mar Biol Ecol 366:37-47

Burcharth HF, Hawkins SJ, Zanuttigh B, Lamberti A (2007) Environmental design guidelines for low crested coastal structures. Elsevier, Oxford

Burrows MT, Hawkins SJ (1998) Modelling patch dynamics on rocky shores using deterministic cellular automata. Mar Ecol Prog Ser 167:1-13

Burrows MT, Hawkins SJ, Southward AJ (1992) A comparison of reproduction in co-occurring chthamalid barnacles, Chthamalus stellatus (Poli) and Chthamalus montagui Southward. J Exp Mar Biol Ecol 160:229-249

Burrows MT, Harvey R, Robb L (2008) Wave exposure indices from digital coastlines and the prediction of rocky shore community structure. Mar Ecol Prog Ser 353:1-12

Burrows MT, Harvey R, Robb L, Poloczanska ES and others (2009) Spatial scales of variance in abundance of intertidal species: effects of region, dispersal mode, and trophic level. Ecology 90:1242-1254

> Coleman RA, Underwood AJ, Benedetti-Cecchi L, Åberg P and others (2006) A continental scale evaluation of the role of limpet grazing on rocky shores. Oecologia 147:556-564

- Coma R, Ribes M, Serrano E, Jimenez E, Salat J, Pascual J (2009) Global warming-enhanced stratification and mass mortality events in the Mediterranean. Proc Natl Acad Sci USA 106:6176-6181

Connell JH (1961) The influence of interspecific competition and other factors on the distribution of the barnacle Chthamalus stellatus. Ecology 42:710-723

Connell JH, Tracey JG, Webb LJ (1984) Compensatory recruitment, growth, and mortality as factors maintaining rain forest tree diversity. Ecol Monogr 54:141-164

Crisp DJ (1964) The effects of the severe winter of 1962-63 on marine life in Britain. J Anim Ecol 33:179-210

> Crisp DJ, Southward AJ (1958) The distribution of intertidal organisms along the coasts of the English Channel. J Mar Biol Assoc UK 37:157-208

> Crisp DJ, Southward AJ, Southward EC (1981) On the distribution of the intertidal barnacles Chthamalus stellatus, Chthamalus montagui and Euraphia depressa. J Mar Biol Assoc UK 61:359-380

> Davies AJ, Johnson MP, Maggs CA (2007) Limpet grazing and loss of Ascophyllum nodosum on decadal time scales. Mar Ecol Prog Ser 339:131-141

Davies AJ, Johnson MP, Maggs CA (2008) Subsidy by Ascophyllum nodosum increases growth rate and survivorship of Patella vulgata. Mar Ecol Prog Ser 366:43-48

Dayton P, Curran S, Kitchingman A, Wilson M and others (2005) Coastal systems. In: Hassan R, Scholes R, Ash N (eds) Ecosystems and human well-being: current state and trends, Vol I. Island Press, Washington, DC, p 513-550

Dulvy NK, Jennings S, Rogers SI, Maxwell DL (2006) Threat and decline in fishes: an indicator of marine biodiversity. Can J Fish Aquat Sci 63:1267-1275

- Edwards M, Richardson AJ (2004) Impact of climate change on marine pelagic phenology and trophic mismatch. 
Nature 430:881-884

Emmerson MC, Solan M, Emes C, Paterson DM, Raffaelli D (2001) Consistent patterns and the idiosyncratic effects of biodiversity in marine ecosystems. Nature 411:73-77

Fischer-Piette E (1936) Etudes sur la biogeographie intercotidale des deux rives de la Manche. J Linn Soc Lond Zool 40:181-272

Fischer-Piette E (1955) Repartition, le long des cotes septentrionales de l'Espagne, des principales especes peuplant les rochers intercotidaux. Ann Inst Ocenaogr Monaco 31: $37-124$

Forbes E (1858) The distribution of marine life, illustrated chiefly by fishes and molluscs and radiata. In: Johnston AK (ed) AK Johnston's physical atlas. W \& AK Johnston, Edinburgh, p 99-101

Gaines SD, Gaylord B, Gerber LR, Hastings A, Kinlan BP (2007) Connecting places: the ecological consequences of dispersal in the sea. Oceanography 20:90-99

Genner MJ, Sims DW, Wearmouth VJ, Southall EJ, Southward AJ, Henderson PA, Hawkins SJ (2004) Regional climatic warming drives long-term community changes of British marine fish. Proc R Soc Lond B Biol Sci 271: 655-661

> Gray JS (1997) Marine biodiversity: patterns, threats and conservation needs. Biodivers Conserv 6:153-175

> Griffin JN, de la Haye KL, Hawkins SJ, Thompson RC, Jenkins SR (2008) Predator diversity and ecosystem functioning: density modifies the effect of resource partitioning. Ecology 89:298-305

Griffin JN, Mendez V, Johnson AF, Jenkins SR, Foggo A (2009) Functional diversity predicts overyielding effect of species combination on primary productivity. Oikos 118: $37-44$

Hansson LJ, Hudson IR, Seddon RJ, Shaw O, Thomason JC (2003) Massive recruitment of the barnacle Semibalanus balanoides in the Clyde Sea (Scotland, UK) in the spring of 2000. J Mar Biol Assoc UK 83:923-924

Harley CDG (2008) Tidal dynamics, topographic orientation, and temperature-mediated mass mortalities on rocky shores. Mar Ecol Prog Ser 371:37-46

Harley CDG, Hughes AR, Hultgren KM, Miner BG and others (2006) The impacts of climate change in coastal marine systems. Ecol Lett 9:228-241

Hartnoll RG, Hawkins SJ (1985) Patchiness and fluctuations on moderately exposed rocky shores. Ophelia 24:53-64

- Hawkins SJ (1981) The influence of season and barnacles on algal colonization of Patella vulgata (L.) exclusion areas. J Mar Biol Assoc UK 61:1-15

Hawkins SJ (1983) Interaction of Patella and macroalgae with settling Semibalanus balanoides (L.). J Exp Mar Biol Ecol 71:55-72

Hawkins SJ, Harkin E (1985) Preliminary canopy removal in algal dominated communities low on the shore and in the shallow subtidal. Bot Mar 28:223-230

Hawkins SJ, Hartnoll RG (1983) Grazing of intertidal algae by marine invertebrates. Oceanogr Mar Biol Annu Rev 21: 195-282

> Hawkins SJ, Hartnoll RG (1985) Factors determining the upper limits of intertidal canopy-forming algae. Mar Ecol Prog Ser 20:265-271

Hawkins SJ, Southward AJ, Barrett RL (1983) Population structure of Patella vulgata during succession on rocky shores in south-west England. Oceanol Acta Special Volume:103-107

> Hawkins SJ, Watson DC, Hill AS, Harding SP, Kyriakides MA, Hutchinson S, Norton TA (1989) A comparison of feeding mechanisms in microphagus, herbivorous, intertidal, prosobranchs in relation to resource partitioning.
J Molluscan Stud 55:151-165

Hawkins SJ, Hartnoll RG, Kain JM, Norton TA (1992) Plant-animal interactions on hard substrata in northeast Atlantic. In: John DM, Hawkins SJ, Price JH (eds) Plant-animal interactions in the marine benthos. Oxford University Press, Oxford, p 1-32

- Hawkins SJ, Southward AJ, Genner MJ (2003) Detection of environmental change in a marine ecosystem: evidence from the western English Channel. Sci Total Environ 310: $245-256$

> Hawkins SJ, Moore PJ, Burrows MT, Poloczanska E and others (2008) Complex interactions in a rapidly changing world: responses of rocky shore communities to recent climate change. Clim Res 37:123-133

> Hector A, Schmid B, Beierkuhnlein C, Caldeira MC and others (1999) Plant diversity and productivity experiments in European grasslands. Science 286:1123-1127

- Helmuth B, Mieszkowska N, Moore P, Hawkins SJ (2006) Living on the edge of two changing worlds: forecasting responses of rocky intertidal ecosystems to climate change. Annu Rev Ecol Evol Syst 37:373-404

Herbert RJ, Hawkins SJ, Sheader M, Southward AJ (2003) Range extension and reproduction of the barnacle Balanus perforatus in the eastern English channel. J Mar Biol Assoc UK 83:73-82

> Herbert RJH, Southward AJ, Sheader M, Hawkins SJ (2007) Influence of recruitment and temperature on distribution of intertidal barnacles in the English Channel. J Mar Biol Assoc UK 87:487-499

Herbert RJH, Southward AJ, Clarke RT, Sheader M, Hawkins SJ (2009) Persistent border: an analysis of the geographic boundary of an intertidal species. Mar Ecol Prog Ser 379: $135-150$

> Hiscock K, Southward AJ, Tittley I, Hawkins SJ (2004) Effects of changing temperature on benthic marine life in Britain and Ireland. Aquat Conserv 14:333-362

> Hooper DU, Chapin FS, Ewel JJ, Hector A and others (2005) Effects of biodiversity on ecosystem functioning: a consensus of current knowledge. Ecol Monogr 75:3-35

Hughes JB, Daily GC, Ehrlich PR (1997) Population diversity: its extent and extinction. Science 278:689-692

Hulme M, Jenkins GJ, Lu X, Turnpenny JR and others (2002) Climate change scenarios for the United Kingdom: the UKCIP02 scientific report. Tyndall Centre for Climate Change Research, School of Environmental Sciences, University of East Anglia, Norwich

> Hutchins LW (1947) The basis for temperature zonation in geographical distribution. Ecol Monogr 17:325-335

Hyder K, Aberg P, Johnson MP, Hawkins SJ (2001) Models of open populations with space limited recruitment: extension of theory and application to the barnacle Chthamalus montagui. J Anim Ecol 70:853-863

Ingolfsson A, Hawkins SJ (2008) Slow recovery from disturbance: a 20 year study of Ascophyllum canopy clearances. J Mar Biol Assoc UK 88:689-691

IPCC (2007) Climate change 2007: the physical science basis. Contribution of Working Group I to the Fourth Assessment Report of the Intergovernmental Panel on Climate Change. Cambridge University Press, Cambridge

> Jenkins SR, Hawkins SJ, Norton TA (1999a) Direct and indirect effects of a macroalgal canopy and limpet grazing in structuring a sheltered intertidal community. Mar Ecol Prog Ser 188:81-92

> Jenkins SR, Hawkins SJ, Norton T (1999b) Interaction between a fucoid canopy and limpet grazing in structuring a low shore intertidal community. J Exp Mar Biol Ecol 233:41-63

Jenkins SR, Norton T, Hawkins SJ (1999c) Settlement and 
post-settlement interactions between Semibalanus balanoides (L.) (Crustacea: Cirripedia) and three species of fucoid canopy algae. J Exp Mar Biol Ecol 236:49-67

Jenkins SR, Aberg P, Cervin G, Coleman RA and others (2000) Spatial and temporal variation in settlement and recruitment of the intertidal barnacle Semibalanus balanoides (L.) (Crustacea: Cirripedia) over a European scale. J Exp Mar Biol Ecol 243:209-225

Jenkins SR, Coleman RA, Della Santina P, Hawkins SJ, Burrows MT, Hartnoll RG (2005) Regional scale differences in the determinism of grazing effects in the rocky intertidal. Mar Ecol Prog Ser 287:77-86

Johnson MP, Hughes RN, Burrows MT, Hawkins SJ (1998) Beyond the predation halo: small scale gradients in barnacle populations affected by the relative refuge value of crevices. J Exp Mar Biol Ecol 231:163-170

Jones NS (1948) Observations and experiments on the biology of Patella vulgata at Port St. Mary, Isle of Man. Proc Trans Liverpool Biol Soc 56:60-77

> Jones SJ, Mieszkowska N, Wethey DS (2009) Linking thermal tolerances and biogeography: Mytilus edulis (L.) at its southern limit on the east coast of the United States. Biol Bull 217:73-85

> Jonsson PR, Granhag L, Moschella PS, Aberg P, Hawkins SJ, Thompson RC (2006) Interactions between wave action and grazing control: the distribution of intertidal macroalgae. Ecology 87:1169-1178

Kaiser MJ, Graham N, Rose CS, Wiebe PH (2007) Ecosystemsensitive approaches to fishing: reconciling fisheries with conservation through improvements in fishing technology. ICES J Mar Sci 64:1610-1611

Kendall MA, Bowman RS, Williamson P, Lewis JR (1985) Annual variation in the recruitment of Semibalanus balanoides on the north Yorkshire coast 1969-1981. J Mar Biol Assoc UK 65:1009-1030

Kendall MA, Williamson P, Garwood PR (1987) Annual variation in recruitment and population structure of Monodonta lineata and Gibbula umbilicalis populations at Aberaeron, mid-Wales. Estuar Coast Shelf Sci 24:499-511

Kendall MA, Burrows MT, Southward AJ, Hawkins SJ (2004) Predicting the effects of marine climate change on the invertebrate prey of the birds of rocky shores. Ibis 146: $40-47$

Kordas RL, Dudgeon S (2009) Modeling variation in interaction strength between barnacles and fucoids. Oecologia 158:717-731

Leonard GH (2000) Latitudinal variation in species interactions: a test in the New England rocky intertidal zone. Ecology 81:1015-1030

Lewis JR (1964) The ecology of rocky shores. Hodder \& Stoughton, London

Lima FP, Queiroz N, Ribeiro PA, Hawkins SJ, Santos AM (2006) Recent changes in the distribution of a marine gastropod, Patella rustica Linnaeus, 1758, and their relationship to unusual climatic events. J Biogeogr 33:812-822

Lima FP, Ribeiro PA, Queiroz N, Hawkins SJ, Santos AM (2007a) Do distributional shifts of northern and southern species of algae match the warming pattern? Glob Change Biol 13:2592-2604

Lima FP, Ribeiro PA, Queiroz N, Xavier R, Tarroso P, Hawkins SJ, Santos AM (2007b) Modelling past and present geographical distribution of the marine gastropod Patella rustica as a tool for exploring responses to environmental change. Glob Change Biol 13:2065-2077

Ling SD (2008) Range expansion of a habitat-modifying species leads to a loss of taxonomic diversity: a new and impoverished reef state. Oecologia 156:883-894

Ling SD, Johnson CR, Frusher S, King CK (2008) Reproduc- tive potential of a marine ecosystem engineer at the edge of a newly expanded range. Glob Change Biol 14:907-915

> Ling SD, Johnson CR, Ridgeway K, Hobday AJ, Haddon M (2009) Climate-driven range extension of a sea urchin: inferring future trends by analysis of recent population dynamics. Glob Change Biol 15:719-731

Loreau M, Naeem S, Inchausti P (2002) Biodiversity and ecosystem functioning: synthesis and perspectives. Oxford University Press, Oxford

Lorenzen S (2007) The limpet Patella vulgata L. at night in air: effective feeding on Ascophyllum nodosum monocultures and stranded seaweeds. J Molluscan Stud 73:267-274

Mackenzie BR, Schiedek D (2007) Daily ocean monitoring since the 1860s shows record warming of northern European seas. Glob Change Biol 13:1335-1347

Maggi E, Bertocci I, Vaselli S, Benedetti-Cecchi L (2009) Effects of changes in number, identity and abundance of habitat-forming species on assemblages of rocky seashores. Mar Ecol Prog Ser 381:39-49

Menge BA, Chan F, Nielsen KJ, Lorenzo ED, Lubchenco J (2009) Climatic variation alters supply-side ecology: impact of climate patterns on phytoplankton and mussel recruitment. Ecol Monogr 79:379-395

Mieszkowska N, Leaper R, Moore P, Kendall MA and others (2005) Assessing and predicting the influence of climate change challenging intertidal rocky shore biota: final report for United Kingdom funders. Report No. 20, Marine Biological Association of the UK, Plymouth

Mieszkowska N, Kendall MA, Hawkins SJ, Leaper R, Williamson P, Hardman-Mountford NJ, Southward AJ (2006) Changes in the range of some common rocky shore species in Britain: a response to climate change? Hydrobiologia 555:241-251

Mieszkowska N, Hawkins SJ, Burrows MT, Kendall MA (2007) Long-term changes in the geographic distribution and population structures of Osilinus lineatus (Gastropoda: Trochidae) in Britain and Ireland. J Mar Biol Assoc UK 87:537-545

Miller SL, Vadas RL (1984) The population biology of Ascophyllum nodosum: biological and physical factors affecting survivorship of germlings. Br Phycol J 19:198

Moore HB, Kitching JA (1939) The biology of Chthamalus stellatus (Poli). J Mar Biol Assoc UK 23:521-541

Moore P, Hawkins SJ, Thompson RC (2007a) Role of biological habitat amelioration in altering the relative responses of congeneric species to climate change. Mar Ecol Prog Ser 334:11-19

> Moore P, Thompson RC, Hawkins SJ (2007b) Effects of grazer identity on the probability of escapes by a canopy-forming macroalga. J Exp Mar Biol Ecol 344:170-180

Moschella PS, Abbiati M, Aberg P, Airoldi L and others (2005) Low-crested coastal defence structures as artificial habitats for marine life: using ecological criteria in design. Coast Eng 52:1053-1071

Naeem S (2006) Expanding scales in biodiversity-based research: challenges and solutions for marine systems. Mar Ecol Prog Ser 311:273-283

Naeem S, Hakansson K, Lawton JH, Crawley MJ, Thompson LJ (1996) Biodiversity and plant productivity in a model assemblage of plant species. Oikos 76:259-264

O'Connor NE, Crowe TP (2005) Biodiversity loss and ecosystems functioning: distinguishing between number and identity of species. Ecology 86:1783-1796

> Parmesan C (1996) Climate and species' range. Nature 382: 765-766

Parmesan C (2006) Ecological and evolutionary responses to recent climate change. Annu Rev Ecol Evol Syst 37: $637-669$ 
Parmesan C (2007) Influences of species, latitudes and methodologies on estimates of phenological response to global warming. Glob Change Biol 13:1860-1872

Parmesan C, Yohe G (2003) A globally coherent fingerprint of climate change impacts across natural systems. Nature 421:37-42

$>$ Pearson GA, Lago-Leston A, Mota C (2009) Frayed at the edges: selective pressure and adaptive response to abiotic stressors are mismatched in low diversity edge populations. J Ecol 97:450-462

$>$ Perry AL, Low PJ, Ellis JR, Reynolds JD (2005) Climate change and distribution shifts in marine fishes. Science 308:1912-1915

Poloczanska E, Babcock RC, Butler A, Hobday A and others (2007) Climate change and Australian marine life. Oceanogr Mar Biol Annu Rev 45:407-478

Poloczanska E, Hawkins SJ, Southward AJ, Burrows MT (2008) Modelling the response of populations of competing species to climate change. Ecology 89:3138-3149

Polunin N (2008) Aquatic ecosystems: trends and global perspectives. Cambridge University Press, Cambridge

Raffaelli D, Hawkins SJ (1999) Intertidal ecology. Kluwer, London

Rayner NA, Brohan P, Parker DE, Folland CK and others (2006) Improved analyses of changes and uncertainties in sea surface temperatures measured in situ since the mid-nineteenth century: the HadSST2 data set. J Clim 19: 446-469

Roughgarden J, Iwasa Y, Baxter C (1985) Demographictheory for an open marine population with space-limited recruitment. Ecology 66:54-67

Roughgarden J, Pennington T, Alexander S (1994) Dynamics of the rocky intertidal zone with remarks on generalisation in ecology. Philos Trans R Soc Lond B Biol Sci 343:79-85

Schonbeck M, Norton TA (1978) Factors controlling upper limits of fucoid algae on shore. J Exp Mar Biol Ecol 31: $303-313$

Sheppard C (2004) Sea surface temperature 1871-2099 in 14 cells around the United Kingdom. Mar Pollut Bull 49: $12-16$

Simkanin C, Powers A, Myers A, McGrath D and others (2005) Using historical data to detect temporal changes in the abundances of intertidal species on Irish shores. J Mar Biol Assoc UK 85:1329-1340

Sims DW, Genner MJ, Southward AJ, Hawkins SJ (2001) Timing of squid migration reflects North Atlantic climate variability. Proc R Soc Lond B Biol Sci 268:2607-2611

Sims DW, Wearmouth VJ, Genner MJ, Southward AJ, Hawkins SJ (2004) Low-temperature-driven early spawning migration of a temperate marine fish. J Anim Ecol 73:333-341

Solan M, Raffaelli DG, Paterson DM, White PCL, Pierce GJ (2006) Introduction. Marine biodiversity and ecosystem function: empirical approaches and future research needs. Mar Ecol Prog Ser 311:175-178

Southward AJ (1964) Limpet grazing and the control of vegetation on rocky shores. In: Crisp DJ (ed) Grazing in terrestrial and marine environments. Blackwell, Oxford, p 265-273

Southward AJ (1967) Recent changes in abundance of intertidal barnacles in south-west England, a possible effect of climatic deterioration. J Mar Biol Assoc UK 47:81-95

Southward AJ (1976) On the taxonomic status and distribution of Chthamalus stellatus in the north east Atlantic region. J Mar Biol Assoc UK 56:1007-1028

Southward AJ (1980) The western English Channel-an inconstant ecosystem? Nature 285:361-366

Southward AJ (1991) 40 years of changes in species composition and population-density of barnacles on a rocky shore near Plymouth. J Mar Biol Assoc UK 71:495-513

Southward AJ, Crisp DJ (1954a) The distribution of certain intertidal animals around the Irish coast. Proc R Ir Acad B $57: 1-29$

Southward AJ, Crisp DJ (1954b) Recent changes in the distribution of the intertidal barnacles Chthamalus stellatus Poli and Balanus balanoides in the British Isles. J Anim Ecol 23:163-177

> Southward AJ, Crisp DJ (1956) Fluctuations and abundance in the distribution and abundance of intertidal barnacles. J Mar Biol Assoc UK 35:211-229

Southward AJ, Southward EC (1978) Recolonisation of rocky shores in Cornwall after the use of toxic dispersants to clean up the Torrey Canyon oil spill. J Fish Res Board Can 35:682-706

Southward AJ, Southward EC (1988) Disappearance of the warm-water hermit crab Clibanarius erythropus from southwest Britain. J Mar Biol Assoc UK 68:409-412

> Southward AJ, Hawkins SJ, Burrows MT (1995) 70 years observations of changes in distribution and abundance of zooplankton and intertidal organisms in the western English Channel in relation to rising sea temperature. J Therm Biol 20:127-155

Southward AJ, Langmead O, Hardman-Mountford NJ, Aiken $\mathrm{J}$ and others (2005) Long-term oceanographic and ecological research in the western English Channel. Adv Mar Biol 47:1-105

Svensson CJ, Jenkins SR, Hawkins SJ, Aberg PA (2005) Population resistance to climate change: modelling the effects of low recruitment in open populations. Oecologia 142: $117-126$

Svensson CJ, Johansson E, Aberg P (2006) Competing species in a changing climate: effects of recruitment disturbances on two interacting barnacle species. J Anim Ecol 75:765-776

> Terlizzi A, Scuderi D, Fraschetti S, Anderson MJ (2005) Quantifying effects of pollution on biodiversity: a case study of highly diverse molluscan assemblages in the Mediterranean. Mar Biol 148:293-305

Thomas MLH (1986) A physically derived exposure index for marine shorelines. Ophelia 25:1-13

Thompson RC, Wilson BJ, Tobin ML, Hill AS, Hawkins SJ (1996) Biologically generated habitat provision and diversity of rocky shore organisms at a hierarchy of spatial scales. J Exp Mar Biol Ecol 202:73-84

> Thompson RC, Norton TA, Hawkins SJ (2004) Physical stress and biological regulation control pattern and process in benthic biofilms. Ecology 85:1372-1382

Thorson G (1950) Reproductive and larval ecology of marine bottom invertebrates. Biol Rev Camb Philos Soc 25:1-45

- Tilman D, Reich PB, Knops JMH (2006) Biodiversity and ecosystem stability in a decade-long grassland experiment. Nature 441:629-632

Wethey DS (1980) Consequences of variation in settlement of inter-tidal barnacles. Am Zool 20:947

Wethey DS (1982) Inter-tidal zonation and geographic limits: the barnacles Balanus and Chthamalus in New England. Am Zool 22:883

> Wethey DS, Woodin SA (2008) Ecological hindcasting of biogeographic responses to climate change in the European intertidal zone. Hydrobiologia 606:139-151

> Woehrling D, Lefebvre A, Fevre-Lehorff GL, Delesmont R (2005) Seasonal and longer term trends in sea temperature along the French North Sea coast 1975-2002. J Mar Biol Assoc UK 85:39-48

Wootton JT, Pfister CA, Forester JD (2008) Dynamic patterns and ecological impacts of declining ocean $\mathrm{pH}$ in a highresolution multi-year dataset. Proc Natl Acad Sci USA 105: 18848-18853 